\title{
EFFECT OF POTASSIUM SILICATE, VERMICOMPOST TEA AND BIO FERTILIZER TREATMENTS ON "ARRA15" GRAPE BERRIES QUALITY AT HARVEST AND DURING STORAGE
}

\author{
H.G. Elmehrat ${ }^{(1)}$, A.M.R.A. Abdelaziz ${ }^{(1)}$ and M.A.A. Mohamed ${ }^{(2)}$ \\ (1) Central Lab. of Organic Agriculture, Agricultural Research Center, Giza, Egypt. \\ (2) Fruit Handling Département, Horticulture Research Institute, ARC, Giza, Egypt.
}

Received: Mar. 21, 2018

Accepted: Apr. 5, 2018

\begin{abstract}
Grapes are one of the most important horticultural crops in Egypt. The "ARRA 15" table grape vines variety is one of the most recently produced varieties introduced into Egypt. This study was carried out to show the nature of their growth and nutritional needs as well as their storage behavior under Egyptian environmental conditions during two seasons (2016 and 2017) on grapes vines grown in a private farm at El Sadat City, El-Menoufia Governorate, Egypt. The effect of three treatments i.e. Potassium silicate (KSi), vermicompost tea (by spraying) and a bio-fertilizer (as soil addition). Potassium silicate and vermicompost tea were sprayed on vines grapes either separately or accompanied, while bio fertilizer was added to soil in the presence of spraying of either potassium silicate or vermicompost tea and sprayed tap water (control). These treatments were carried out during three different stages before harvesting. To study the effect of aforementioned treatments on storability of "ARRA 15" variety, clusters of matured grape fruits were harvested and packed in cartons. The results showed that all treatments either alone or in combination reduced weight loss and decay incidence of clusters under our storage conditions. Deterioration rates quality characteristics of clusters and berry softening were decreased compared to untreated clusters.
\end{abstract}

Key words: Potassium silicate - vermicompost tea - variety "ARRA 15"- cold storage bio-fertilizer

\section{INTRODUCTION}

Grapes (Vitis vinifera, L.) ranks as the second major fruit crop in Egypt following citrus. Vineyards have increased in the last years especially in the newly reclaimed lands. Grapes are considered as one of the promising exported crops in Egypt. However, the exported quantity of the Egyptian grape is still very low in comparison to the Egyptian total grape production. The "ARRA" is early to mid-season, mediumto-large size, white, red and black seedless grape varieties developed by Sun World International. The "ARRA" is the result of several decades of experimentation and development by Messrs. Shachar Karniel and Sal
Giumarra. The Karniel family has always dedicated itself to the cultivation and development of seedless grape varieties, said ARRA breeder Shachar Karniel. "ARRA15" is a unique and appealing white seedless variety. It is very fertile and has a strong vine. The berries are long, cylinder shaped and particularly crunchy. Its creamy, light green color together with its bright waxy appearance makes it very appealing to customers.

The use of natural preharvest treatments such as spraying potassium silicate, vermicompost tea and bio fertilizer as plant growth promoting regulators(PGPR) is necessary to maintain the fruit quality during a longdistance transportation and a long-term 
storage (Meng et al., 2008; Zoffoli et al., 2008 and 2009).

Vermicompost tea are products derived from the accelerated biological degradation of organic wastes by earthworms and microorganisms (Edwards et al., 2004). Vermicompost tea is rich in mineral elements than commercial plant growth media. This mineral elements are available in the forms that could be taken up by plants such as nitrates, orthophosphates, soluble $\mathrm{K}, \mathrm{Ca}, \mathrm{Mg}$ and plant growth promoting regulators (PGPR), that can produce considerable amounts of many plant growth regulators such as auxins, gibberellins, cytokinins, humic acid, and as well as their metal complexation properties and behavior (Muscolo et al., 1999; Edwards et al., 2004; Arancon et al., 2004 and 2005, Javed et al., 2017). Venkatesh et al., 1998, it has been reported that, vermicompost application caused significant increases in cv. Pinnot Noir grapes yield by $55 \%$, in addition, application of vermicompost significantly improved King's Ruby fruit physical characteristics like clusters weight and yield (Javed et al., 2017). Muhammad et al., (2017) indicated that, application of vermicompost significantly improved fruit physical and chemical characteristics like clusters weight, TSS, TA, RS, TS and yield of table grapes cv. King's Ruby. This may result in greater price in the market, since larger bunches are more appreciated in the market. Uwakiem, (2015) mentioned that, Early Sweet Grape vines sprayed three times at starting of vegetative growth with a mixture containing humic acid and potassium silicate each at $0.1 \%$ and selenium at $0.05 \%$ had significantly higher productivity and berry quality. Bhat and Khambata, (1996) reported that, compost tea had a positive impact and induced significant increase of strawberries yield. The same trend was mentioned by (Arancon et al., 2004; Verma et al., 2015 and Pane et al., 2016) on tomatoes. Also they added that, using vermicompost as a soil additive increased tomatoes fruit Vitamin $C$ and total sugar contents during growth and maturation. Zhang et al., (2017) declared that, fruit yield, cluster weight, berry weight, berry size were significantly increased by application of silicon fertilizers in Red globe and Monukka table grapes at harvest. Moreover, they obtained that, Silicon fertilization significantly increased fruit total soluble solids (TSS) contents and fruit firmness. They also added that, these treatments significantly extended the fruit shelf-life by decreasing decay incidence and weight loss of fruits during storage. (Takma and Korel, 2017) found that, Alginate treatments were effective in preventing weight and firmness losses during storage. Scarlet grapevine (Vitis vinifera L.) canopies and clusters at version and prior to harvest with aqueous potassium solutions was reported to increase soluble solids concentration (SSC) in grape berries at harvest (Obenland et al., 2015). Moreover, they added that, these treatments increased 'Flame Seedless' grape berries darkness at harvest. On the other side, these applications that caused the most rapid loss in berry weight were those that caused the largest increase in SSC of berries during storage.

Mohamed et al., (2017) illustrated that, pre-harvest application of potassium silicate and calcium chloride as spraying treatments are a promising strategy for the management fruit quality of mango cv. "Zibda" fruits during cold storage and increased its storage life up to five weeks. The only effect of high potassium fertilization was an increase of total soluble solids and a decrease of acid concentration. Abd El-Razek et al., (2011). Decrease in juice titratable acidity percentages with the enhancement of 
potassium(K) levels were due to interaction with tartaric acid in the form of potassium tartrate which has limited solubility (Davies et al., 2006) and (Kelany et al., 2011). The role of potassium fertilization in reducing the acid levels in berries could be due to the reduction in tartaric acid when it was converted into potassium tartarate (Davies et al., 2006) and (Saleh et al., 2007).

The aim of this study is to determine the effect of pre-harvest soil and foliar application with vermicompost tea, potassium silicate and bio fertilizer as PGPR on "ARRA 15" new cultivar fruit quality and storability.

\section{MATERIALS AND METHODS}

This investigation was carried out during two successive seasons, 2016 and 2017. Grapevines were 3 year-old, grown in a private farm at El Sadat area, ElMenoufia Governorate, Egypt. Vines were planted on sandy soil at $1.5 \times 3 \mathrm{~m}$., trained according to Baron-h modified system under drip irrigation system. Vines were treated regularly as the breeder and Ministry of Agriculture recommendation. The mechanical, physical and chemical analyses of the studied soil according to (Jackson, 1973) were shown in Table (1).

\section{Bio-fertilizer as Plant growth promoting rhizobactria (PGPR): \\ PGPR are used as bio-fertilizers and} the bacterial used were Azotobacter chroococum as free $\mathrm{N}$-fixing bacteria, Bacillus megathreum as phosphate dissolving bacteria and Bacillus circulans as potassium release bacteria. The mixed cultural from pervious bacteria were used at rate $10 \mathrm{~L}_{/} \mathrm{fed}^{-1}$, the number for each culture was $\left(-\times 10{ }^{9}\right.$ cell $I$ mel) Liquid culture.

\section{Vermicompost tea:}

Vermicompost are the products derived from accelerated biological degradation of organic wastes by interaction between earthworms and microorganisms (1verm:10 water), Properties of vermicompost tea. The chemical analysis of vermicompost tea used was shown in Table (2).

Table (1): The mechanical, physical and chemical properties of the studied soil.

\begin{tabular}{|l|c|c|c|}
\hline \multicolumn{1}{|c|}{ Property } & Values & Property & Values \\
\hline Coarse Sand\% & 59.43 & T.N \% & 0.009 \\
Fine Sand\% & 31.37 & Soluble Cations $\left(\mathrm{meg} \mathrm{L}^{-1}\right):$ & \\
Silt\% & 3.81 & $\mathrm{Ca}^{++}$ & 1.39 \\
Clay\% & 5.49 & $\mathrm{Mg}^{++}$ & 1.27 \\
Calcium Carbonate\% & 4.15 & $\mathrm{Na}^{+}$ & 1.30 \\
Texture & Sandy & $\mathrm{K}^{+}$ & 0.48 \\
Water holding Capacity\% & 13.18 & Soluble Anions $\left(\mathrm{meg} \mathrm{L}^{-1}\right):$ & \\
SP\% & 21.20 & $\mathrm{Co}$ & 0.00 \\
PH\% & 7.42 & $\mathrm{H} \mathrm{Co}$ & 1.72 \\
E.C.\% & 0.51 & $\mathrm{Cl}$ & 0.82 \\
O.M. $\%$ & 0.33 & $\mathrm{SO}_{4}$ & 1.96 \\
\hline
\end{tabular}

Table (2): The chemical properties of vermicompost tea used

\begin{tabular}{|c|c|c|c|c|c|c|c|c|c|c|}
\hline \multirow{2}{*}{$\begin{array}{c}\text { pH } \\
1: 5\end{array}$} & \multirow{2}{*}{$\begin{array}{c}\text { EC } \\
\text { dS/m }\end{array}$} & \multicolumn{10}{|c|}{ ppm } \\
\cline { 3 - 12 } & ${\mathrm{N}-\mathrm{NH}_{4}}_{4}$ & $\mathrm{~N}^{-N_{3}}$ & T.N & T.P & T.K & Fe & Zn & Mn & Cu \\
\hline 8.05 & 2.70 & 8.67 & 35.23 & 809 & 11200 & 13200 & 14.60 & 6.20 & 3.30 & 1.50 \\
\hline
\end{tabular}


Eighteen vines were selected from cultivar as a completely randomized design and divided into 6 groups. Each group has three replicate and each replicate has three vines. Spraying was applied during vegetative growth, both vegetative and clusters were sprayed each time. Vines were sprayed after berry setting (Mid of April), three weeks later $\left(1^{\text {st }}\right.$ week of May) and three weeks later $\left(1^{\text {st }}\right.$ week of June). Vines were sprayed with potassium silicate $\left(\mathrm{K}_{2} \mathrm{O} \quad 10 \%+\mathrm{SiO}_{2}\right.$ 25\%) at $6 \mathrm{mIL}^{-1}$ dose, vermicompost tea at $6 \mathrm{ml} / \mathrm{L}^{-1}\left(5 \mathrm{~L} / \mathrm{Fe}^{-1}\right)$, and PGPR at 10 L/Fadden and tap water (control) as the following:

1- The vines treated with foliar spray of tap water (Control).

2- The vines treated with foliar spray of potassium silicate $\left(\mathrm{K}_{2} \mathrm{O} \quad 10 \%+\mathrm{SiO}_{2}\right.$ 25\%) at $6 \mathrm{ml} / \mathrm{L}^{-1}$ (equal $5 \mathrm{~L} / \mathrm{Fed}^{-1}$.

3- The vines treated with foliar spray of potassium silicate $\left(\mathrm{K}_{2} \mathrm{O} \quad 10 \%+\mathrm{SiO}_{2}\right.$ 25\%) at $6 \mathrm{ml}^{-1}+$ PGPR.

4- The vines treated with foliar spray of vermicompost tea rate $6 \mathrm{ml} / \mathrm{L}^{-1}$ $\left(5 \mathrm{~L} / \mathrm{Fe}^{-1}\right)$.

5- The vines treated with foliar spray of potassium silicate $\left(\mathrm{K}_{2} \mathrm{O} \quad 10 \%+\mathrm{SiO}_{2}\right.$ $25 \%$ ) rate $6 \mathrm{ml} / \mathrm{L}^{-1}+$ vermicompost tea $6 \mathrm{ml} / \mathrm{L}^{-1}\left(5 \mathrm{~L} / \mathrm{Fe}^{-1}\right)$.

6- The vines treated with foliar spray of vermicompost tea rate $6 \mathrm{ml} / \mathrm{L}^{-1}$ $\left(5 \mathrm{~L} / \mathrm{Fe}^{-1}\right)+\mathrm{PGPR}$.

Grape clusters of each treatment were harvested at the beginning of softening and 15 days after, one week before the expected grape maturation. At maturity stage grape clusters were harvested and transported to the Central Lab. of Organic Agriculture, ARC, Giza, where fruits were placed in cardboard boxes, 4 boxes for each treatments and stored at $0^{\circ} \mathrm{C}$ and $90: 95 \% \mathrm{RH}$ for five weeks at Plant Pathology Research Institute refrigerator rooms. Cardboard boxes were examined weekly and samples were withdrawn to determine the other physical and chemical properties.

Grape quality parameters analyzed as follows:

Physical characteristics:

1- Weight Loss percentage (WL \%) was calculated as the following:

Weight Loss percentage $=\frac{A}{B} \times 100$

Where $A=$ Weight Loss value at the time of sampling while $B=$ the initial grape weight.

2- Decay percentage was determined according to the following:

Decay percentage $=\frac{A}{B} \times \mathbf{1 0 0}$

Where $A=$ Decayed berries weight at the time of sampling while

$B=$ the initial grape weight.

3- Berries firmness was determined by using Flfra firmness analyzer equipment by penetrating cylinder 2 $\mathrm{mm}$ diameter to a constant distance with a constant speed $2 \mathrm{~mm} /$ second. The results were expressed as a resistance force of the skin or flesh (lbs /lnch ${ }^{2}$.

\section{Chemical characteristics.}

Freshly prepared of the berry juice samples were used for total soluble solids (TSS), total acidity as tartaric acid (TA) and total sugars (TS) determinations as described by (A.O.A.C., 2003).

\section{Statistical Analysis Procedure:}

All data parameters were analyzed as Completely Randomized Design with three replicates. The obtained data were subjected to statistical analysis as described by Snedecor and Cochran, (1990). The differences between means were differentiated using LSD test at $P \geq$ 0.05 . 


\section{RESULTS AND DISCUSSIONS}

Effect of vermicompost, silicate potassium and bio fertilizer on ARRA 15 clusters properties at harvest:-

Clusters physical properties:-

1- Clusters weight:-

Data presented in Table (3) showed that, clusters weight increased gradually and significantly with the increasing of clusters age during the two seasons in this work. Date also, cleared that all studied treatments significantly increased clusters weight at harvest in comparison with untreated vines. Moreover, vines treated with bio fertilizer and vermicompost tea plus silicate potassium were the most effective in this aspect during the two seasons in this work. These results are in agreement with those findings of vermicompost tea application that caused significant increases in grapes yield (Venkatesh et al., 1998; Mohamed et al., 2013 and Javed et al., 2017). Moreover these results are in line with those obtained by (Bhat and Khambata, 1996) on strawberries and (Arancon et al., 2004; Verma et al., 2015 and Pane et al., 2016) on tomatoes. They demonstrated that, compost tea had increased these crops yield. Otherwise, some of these treatments also significantly increased grape berry weight and size. On the other hand, these results are in accordance with those obtained by (Alrashdi et al., 2017; Lo'ay, 2017; Zhang et al., 2017 and Lo'ay and EL-Boray, 2018). They illustrated that, preharvest application with silicon, salicylic acid, ascorbic acid, chitosan or potassium silicate significantly increased grape vine productivity at harvest. Furthermore, some of these treatments significantly increased grape berry weight and size.

Table (3): Effect of pre-harvest treatments on weight cluster of table grape (cv. ARRA15) at maturation and harvesting.

\begin{tabular}{|c|c|c|c|c|c|c|c|c|c|c|}
\hline \multirow{2}{*}{\begin{tabular}{r|} 
Season \\
Treatment \\
H.D.
\end{tabular}} & \multicolumn{5}{|c|}{$1^{\text {st }}$ season 2016} & \multicolumn{5}{|c|}{$2^{\text {nd }}$ season 2017} \\
\hline & $1^{\text {st }}$ & $2^{\text {nd }}$ & $3^{\text {rd }}$ & $4^{\text {th }}$ & Means & $1^{\text {st }}$ & $2^{\text {nd }}$ & $3^{\text {rd }}$ & $4^{\text {th }}$ & Means \\
\hline Control & 91.7 & 120.0 & 226.7 & 291.7 & 182.5 & 175.7 & 296.7 & 373.3 & 416.7 & 315.6 \\
\hline K Si & 191.7 & 241.7 & 271.7 & 328.0 & 258.3 & 184.7 & 285.0 & 423.3 & 476.7 & 342.4 \\
\hline K Si +Bio & 148.3 & 221.7 & 348.3 & 408.3 & 281.7 & 232.3 & 311.7 & 440.0 & 498.3 & 370.6 \\
\hline Vermi & 106.0 & 156.7 & 218.0 & 325.0 & 201.4 & 250.0 & 323.3 & 371.7 & 443.3 & 347.1 \\
\hline Vermi + K Si & 139.3 & 200.0 & 270.0 & 378.3 & 246.9 & 248.0 & 361.7 & 390.0 & 455.0 & 363.7 \\
\hline Vermi + Bio & 159.3 & 179.3 & 241.7 & 370.0 & 237.6 & 188.3 & 346.7 & 470.0 & 466.7 & 367.9 \\
\hline Means & 139.4 & 186.6 & 262.7 & 350.2 & --- & 213.2 & 320.8 & 411.4 & 459.4 & ---- \\
\hline \multicolumn{11}{|c|}{ LSD Values at $5 \%$} \\
\hline \multicolumn{2}{|c|}{ Factors } & \multicolumn{3}{|c|}{ Treatments $(T)$} & \multicolumn{3}{|c|}{ Harvest Date $(H)$} & \multicolumn{3}{|c|}{$\mathrm{T} \times \mathrm{H}$} \\
\hline \multicolumn{2}{|c|}{$1^{\text {st }}$ season } & \multicolumn{3}{|c|}{11.2} & \multicolumn{3}{|c|}{9.2} & \multicolumn{3}{|c|}{22.5} \\
\hline \multicolumn{2}{|c|}{$2^{\text {nd }}$ season } & \multicolumn{3}{|c|}{22.3} & \multicolumn{3}{|c|}{18.4} & \multicolumn{3}{|c|}{44.7} \\
\hline
\end{tabular}




\section{2- Berry firmness:-}

Data presented in Table (4) showed that, berry firmness decreased gradually and significantly with the increasing of clusters age during the two seasons in this study. Data also, cleared that all studied treatments significantly reduced berry firmness softening rate during growth development. Moreover, it is clear that, the most effective treatments in this aspect were spraying vines with potassium silicate plus PGPR recorded 4.6 and 4.2 (lbs $/ \mathrm{Inch}^{2}$ ) at the two seasons, respectively or $\mathrm{KSi}$ plus vermicompost tea recorded 4.7 and 4.2 during the two seasons, respectively. While in the treatments potassium silicate or vermicompost tea alone recorded $3.90,3.60$ and $3.90,3.80$, during the two seasons, respectively.

These results are in accordance with those declared by (Zhang et al., 2017), as they demonstrated that, preharvest Silicon fertilization treatment significantly increased Red globe and Monukka table berry firmness at harvest.

Clusters Chemical properties:-

Total soluble solid (TSS), titratable acidity (TA) and sugar berry juice contents(TS):-

Data presented in Tables (5, 6 and 7 ) showed that, total soluble solid and sugar berry juice (TS) contents gradually and significantly increased while titratable acidity berry juice contents gradually and significantly decreased with prolonging of clusters age during the two seasons in this work. Date also, cleared that all studied treatments significantly decreased TA at potassium silicate plus PGPR or vermicompost tea treatments.

In general, application of preharvest treatments (potassium silicate plus PGPR or vermicompost tea recorded the higher values for TSS and sugar contents and gave a positive response as compared to other treatments during two seasons.

Table (4): Effect of pre-harvest treatments on Firmness (Ibs $/ \mathrm{Inch}^{2}$ ) of table grape (cv. ARRA15) at maturation and harvesting

\begin{tabular}{|c|c|c|c|c|c|c|c|c|c|c|}
\hline Season & \multicolumn{5}{|c|}{$1^{\text {st }}$ season 2016} & \multicolumn{5}{|c|}{$2^{\text {nd }}$ season 2017} \\
\hline Treatment & $1^{\text {st }}$ & $2^{\text {nd }}$ & $3^{\text {rd }}$ & $4^{\text {th }}$ & Means & $1^{\text {st }}$ & $2^{\text {nd }}$ & $3^{\text {rd }}$ & $4^{\text {th }}$ & Means \\
\hline Control & 3.8 & 3.7 & 3.6 & 3.3 & 3.6 & 3.8 & 3.4 & 3.2 & 2.6 & 3.3 \\
\hline K Si & 5.2 & 4.8 & 4.3 & 3.9 & 4.5 & 4.3 & 4.0 & 3.8 & 3.6 & 3.9 \\
\hline K Si +Bio & 5.1 & 4.7 & 4.4 & 4.0 & 4.6 & 4.6 & 4.3 & 4.2 & 3.9 & 4.2 \\
\hline Vermi & 5.0 & 4.5 & 3.9 & 3.6 & 4.3 & 4.1 & 4.0 & 3.8 & 3.4 & 3.8 \\
\hline Vermi + K Si & 5.3 & 5.1 & 4.4 & 4.1 & 4.7 & 4.4 & 4.3 & 4.2 & 3.8 & 4.2 \\
\hline Vermi + Bio & 4.9 & 4.3 & 4.0 & 3.7 & 4.2 & 4.5 & 4.4 & 4.1 & 3.6 & 4.1 \\
\hline Means & 4.9 & 4.5 & 4.1 & 3.8 & --- & 4.3 & 4.1 & 3.9 & 3.5 & --- \\
\hline \multicolumn{11}{|c|}{ LSD Values at $5 \%$} \\
\hline \multicolumn{2}{|l|}{ Factors } & \multicolumn{3}{|c|}{ Treatments $(T)$} & \multicolumn{3}{|c|}{ Harvest Date $(\mathrm{H})$} & \multicolumn{3}{|c|}{$\mathrm{T} \times \mathrm{H}$} \\
\hline \multicolumn{2}{|l|}{$1^{\text {st }}$ season } & \multicolumn{3}{|c|}{0.24} & \multicolumn{3}{|c|}{0.19} & \multicolumn{3}{|c|}{0.47} \\
\hline \multicolumn{2}{|l|}{$2^{\text {nd }}$ season } & \multicolumn{3}{|c|}{0.24} & \multicolumn{3}{|c|}{0.20} & \multicolumn{3}{|c|}{0.48} \\
\hline
\end{tabular}

$\mathrm{KSi}=$ Potassium silicate

Bio= Bio-fertilizer Vermi=Vermicompost tea 
Table (5): Effect of pre-harvest treatments on TSS\% of table grape (cv. ARRA15) at maturation and harvesting

\begin{tabular}{|c|c|c|c|c|c|c|c|c|c|c|}
\hline Season & \multicolumn{5}{|c|}{$1^{\text {st }}$ season 2016} & \multicolumn{5}{|c|}{$2^{\text {nd }}$ season 2017} \\
\hline $\begin{array}{l}\text { H.D. } \\
\text { Treatment }\end{array}$ & $1^{\text {st }}$ & $2^{\text {nd }}$ & $3^{\text {rd }}$ & $4^{\text {th }}$ & Means & $1^{\text {st }}$ & $2^{\text {nd }}$ & $3^{\text {rd }}$ & $4^{\text {th }}$ & Means \\
\hline Control & 7.5 & 14.4 & 16.1 & 17.5 & 13.9 & 7.3 & 14.3 & 16.1 & 17.1 & 13.7 \\
\hline K Si & 8.0 & 14.3 & 16.4 & 18.1 & 14.2 & 7.4 & 15.5 & 17.1 & 17.7 & 14.4 \\
\hline K Si +Bio & 9.5 & 15.8 & 17 & 18.6 & 15.2 & 8.4 & 16.1 & 17.6 & 18.2 & 15.1 \\
\hline Vermi & 8.5 & 14.4 & 16.5 & 17.3 & 14.2 & 7.9 & 13.9 & 16.9 & 17.3 & 14.0 \\
\hline Vermi + K Si & 9.2 & 14.7 & 16.7 & 18.0 & 14.7 & 7.9 & 14.5 & 17.0 & 17.6 & 14.3 \\
\hline Vermi + Bio & 8.8 & 14.1 & 16.8 & 17.3 & 14.3 & 7.3 & 15.3 & 16.7 & 17.3 & 14.2 \\
\hline Means & 8.6 & 14.6 & 16.6 & 17.8 & --- & 7.7 & 14.9 & 16.9 & 17.5 & --- \\
\hline \multicolumn{11}{|c|}{ LSD Values at $5 \%$} \\
\hline \multicolumn{2}{|l|}{ Factors } & \multicolumn{3}{|c|}{ Treatments $(T)$} & \multicolumn{3}{|c|}{ Harvest Date $(H)$} & \multicolumn{3}{|c|}{$\mathbf{T} \times \mathbf{H}$} \\
\hline \multicolumn{2}{|l|}{$1^{\text {st }}$ season } & \multicolumn{3}{|c|}{0.19} & \multicolumn{3}{|c|}{0.16} & \multicolumn{3}{|c|}{0.38} \\
\hline \multicolumn{2}{|l|}{$2^{\text {nd }}$ season } & \multicolumn{3}{|c|}{0.20} & \multicolumn{3}{|c|}{0.17} & \multicolumn{3}{|c|}{0.40} \\
\hline
\end{tabular}

$\mathrm{KSi}=$ Potassium silicate Bio= Bio-fertilizer Vermi=Vermicompost tea

Table (6): Effect of pre-harvest treatments on total acidity (TA \%) of table grape (cv. ARRA15) at maturation and harvesting

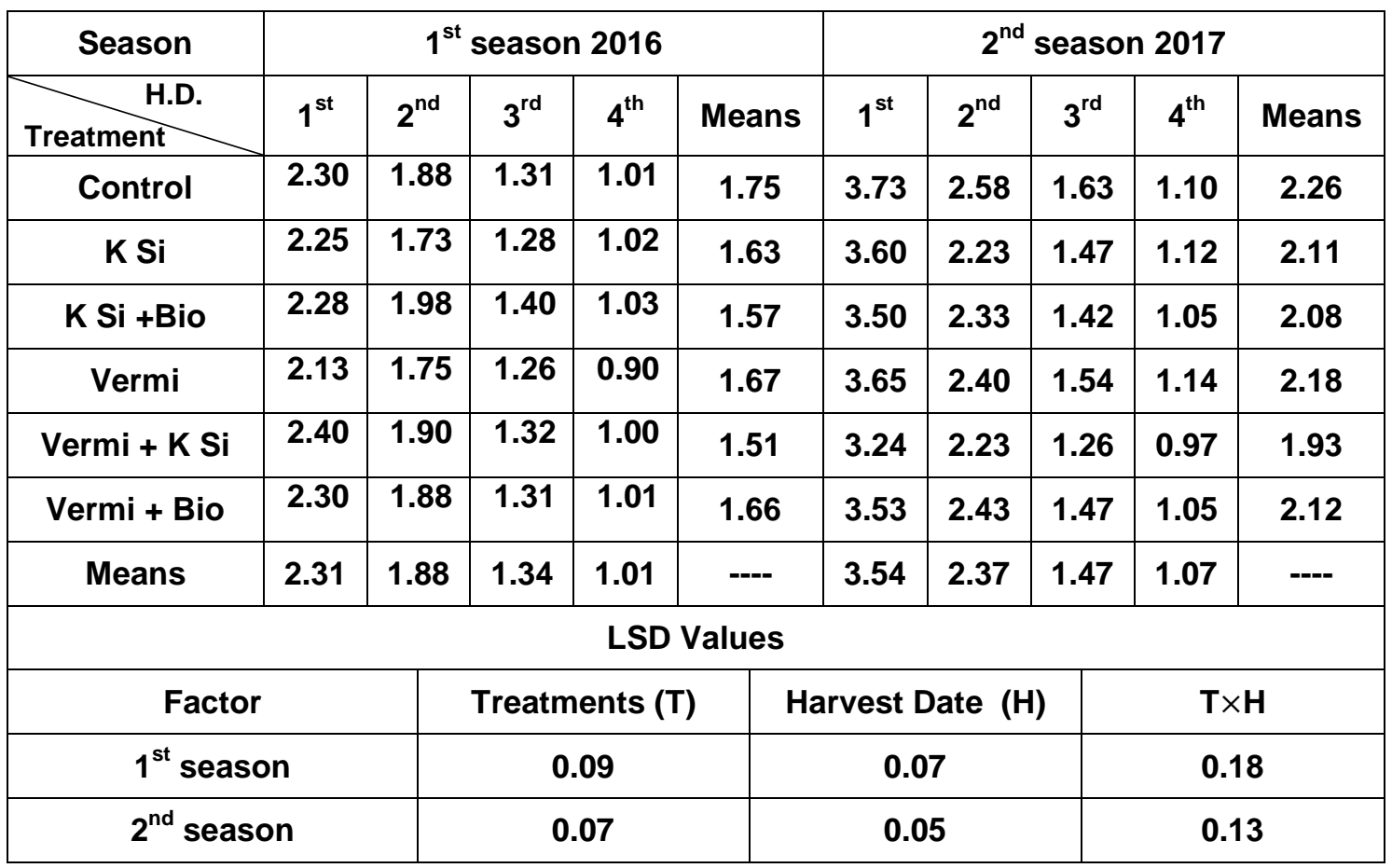

KSi=Potassium silicate Bio= Bio-fertilizer Vermi=Vermicompost tea 
H.G. Elmehrat, et al.,

Table (7): Effect of pre-harvest treatments on total sugar (\%) of table grape (cv. ARRA15) at maturation and harvesting

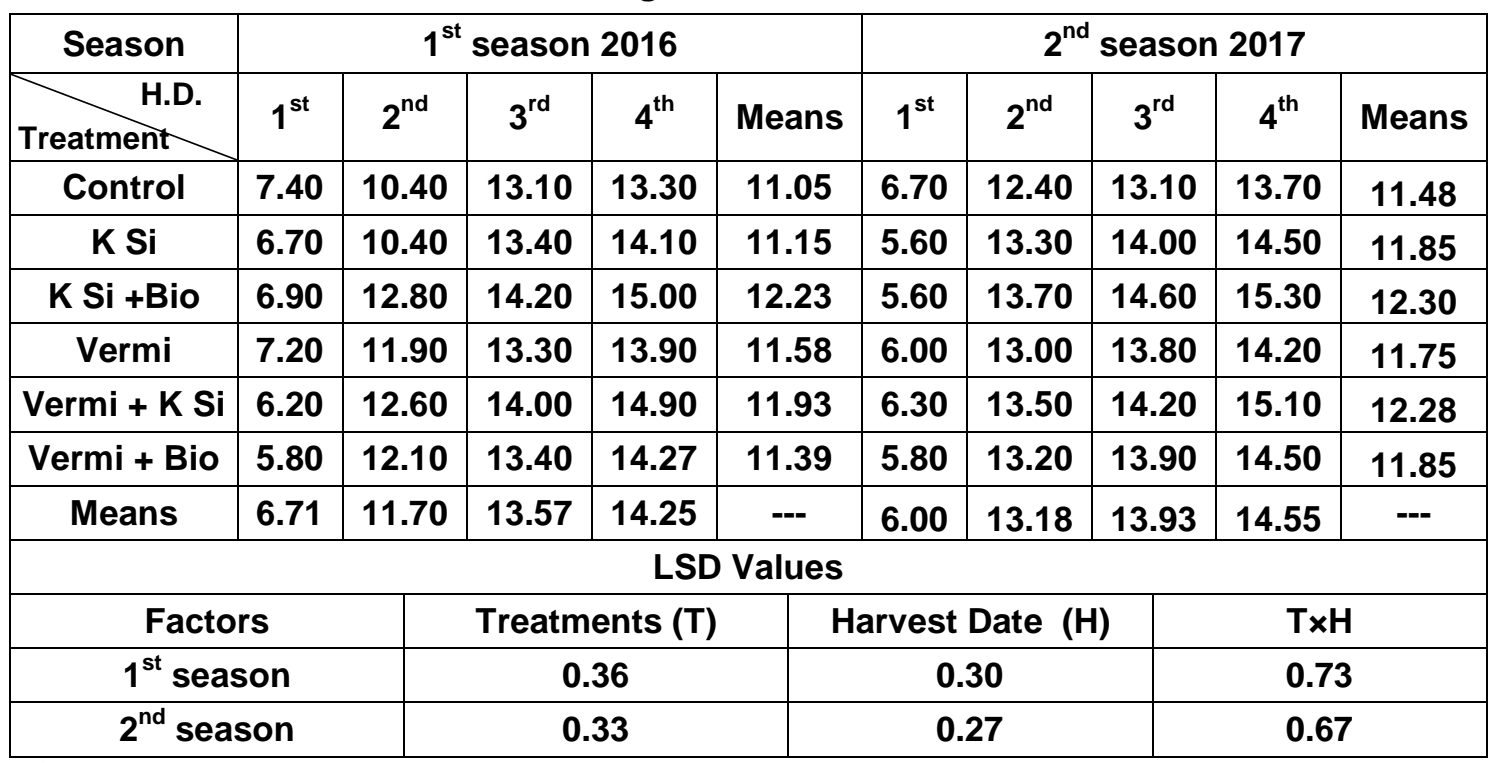

KSi=Potassium silicate Bio= Bio-fertilizer Vermi=Vermicompost tea

These results are in agreement with those obtained by Davies et al., (2006); Saleh et al., (2007) and Kelany et al., (2011). They illustrated that, preharvest application with potassium decreased titratable acidity contents of grape berry juice at harvest. Moreover, these results are in harmony with those mentioned by Abd El-Razek et al., (2011) and Zhang et al., (2017). They demonstrated that, potassium fertilization increased grape juice total soluble solids and decreased of acidity contents at harvest. On contrast these results disagree with those mentioned by Alrashdi et al., (2017), as they illustrated that, preharvest application with salicylic acid and gibberellic acid increased "El-Bayadi" table grape juice acidity contents.

\section{Yield components:}

The value of vine yield $\mathrm{kg}$ and clusters weight Table (8) significantly affected during both seasons with the application of Potassium silicate (KSi) and vermicompost tea which sprayed on grapes either separately or accompanied, while bio fertilizer was added to soil in presence spraying of either potassium silicate or vermicompost tea compared to control value. The increase was significantly associated with Potassium silicate of each compound. Using all the combined application was more effective than single applications. Higher yield was recorded when the vines treated three times with Potassium silicate and addition biofertilizers. Under such promise treatment, yield per vine reached 13.60 and $15.60 \mathrm{Kg}$ during both seasons, respectively. The control vines produced 9.03 and $11.18 \mathrm{Kg}$ during both seasons, respectively. These results are in harmony with (Uwakiem, 2015) who found that, spray the vines three times by a mixture containing humic acid and Potassium silicate improve yield and berry quality of Early Sweet grape vines and Muhammad et al., (2017) cleared that, the application of vermicompost increased the growth, cluster weight and yield table grapes variety King's Ruby. Shown that, the application of vermicompost increased the growth and yield of several crops including banana, peppers and strawberries (Ushakumari et el., 1999; Athani et al., 1999; Nenthra et al., 1999 and Arancon et al., 2004 \& 2005). 
Table (8): Effect of pre-harvest treatments on yield components of table grape (cv. ARRA15) at harvesting

\begin{tabular}{|l|c|c|c|c|c|c|}
\hline \multirow{2}{*}{ Treatments } & \multicolumn{3}{|c|}{$1^{\text {st }}$ season 2016 } & \multicolumn{3}{c|}{$2^{\text {nd }}$ season 2017 } \\
\cline { 2 - 7 } & $\begin{array}{c}\text { Vine yield } \\
\text { kg }\end{array}$ & $\begin{array}{c}\text { Vine } \\
\text { cluster } \\
\text { No }\end{array}$ & $\begin{array}{c}\text { Cluster } \\
\text { weight } \\
\text { g }\end{array}$ & $\begin{array}{c}\text { Vine } \\
\text { yield } \\
\text { kg }\end{array}$ & $\begin{array}{c}\text { Vine } \\
\text { cluster } \\
\text { No }\end{array}$ & $\begin{array}{c}\text { Cluster } \\
\text { weight } \\
\text { g }\end{array}$ \\
\hline Control & 9.03 & 31.67 & 275.00 & 11.18 & 28.00 & 401.67 \\
\hline K Si & 11.17 & 30.33 & 328.00 & 13.43 & 28.00 & 465.00 \\
\hline K Si +Bio & 13.60 & 31.00 & 418.33 & 15.60 & 29.67 & 506.67 \\
\hline Vermi & 10.50 & 31.33 & 325.00 & 12.57 & 28.00 & 435.00 \\
\hline Vermi + K Si & 13.00 & 30.67 & 386.67 & 14.90 & 29.00 & 498.33 \\
\hline Vermi + Bio & 12.22 & 31.00 & 370.00 & 13.68 & 29.00 & 466.67 \\
\hline \multicolumn{1}{|c|}{ LSD at 5\% } & 1.75 & NS & 38.36 & 2.20 & NS & 32.80 \\
\hline
\end{tabular}

KSi=Potassium silicate Bio= Bio-fertilizer Vermi=Vermicompost tea

Fruit Storability:-

Effect of vermicompost tea, silicate potassium and bio-fertilizer on table grape (cv. ARRA15) clusters properties during storage.

\section{1- Fresh Weight Loss and Decay percentage (\%):-}

Data presented in Tables (9 and 10) indicated that, weight loss and decay incidence increased gradually and significantly with prolonging of storage period to reach its maximum at the end of storage period during the two seasons under this investigation.

Data also demonstrated that all preharvest treatments significantly reduced the increasing rate of weight loss and decay incidence of grapes during storage in the two seasons under this investigation. Moreover, it is obvious that, preharvest treatments with $\mathrm{KSi}$ either alone or in combination bio fertilizer had the lowest weight loss incidence during the first season. While during the second season clusters treated with the combination of vermicompost tea and $\mathrm{KSi}$ or vermicompost tea and bio fertilizer had the lowest weight loss incidence.
On the other side, clusters treated with the combination of vermicompost and bio fertilizer or KSi significantly had the lowest decay incidence during the two seasons under this work. These results are in agreement with those obtained by (Mohamed and Ibrahim, 2005; Mohamed et al., 2007; Elzayat and Mohamed, 2008; Mirdehghan and Rahimi, 2016 and Sortino et al., 2017). They mentioned that, weight loss and decay incidence increased gradually and significantly with prolonging of storage period to reach its maximum at the end of storage period.

Moreover, these results are in harmony with those illustrated by (Mirdehghan and Rahimi, 2016; Shen and Yang, 2017; Takma and Korel, 2017 and Zhang et al., 2017). They obtained that, preharvest treatments with chitosan and salicylic acid either as a single or application of silicon (KSi) at three different growth stages significantly decreased weight loss and decay incidence of table grapes during cold storage. 
H.G. Elmehrat, et al.,

Table (9): Effect of pre-harvest treatments on weight loss (\%) of table grape (cv. ARRA15) stored at $0^{\circ} \mathrm{C}$ and $90 \% \mathrm{RH}$.

\begin{tabular}{|c|c|c|c|c|c|c|c|}
\hline \multirow{2}{*}{ Treatments } & \multicolumn{6}{|c|}{ Storage Period weeks } & \multirow{2}{*}{ Means } \\
\hline & $1^{\text {st }}$ & $2^{\text {nd }}$ & $3^{\text {rd }}$ & $4^{\mathrm{th}}$ & $5^{\text {th }}$ & $6^{\text {th }}$ & \\
\hline \multicolumn{8}{|c|}{$1^{\text {st }}$ season 2016} \\
\hline Control & 0.00 & 2.22 & 5.41 & 7.86 & 10.46 & 13.55 & 6.58 \\
\hline K Si & 0.00 & 1.04 & 3.11 & 4.83 & 6.37 & 8.38 & 3.96 \\
\hline K Si +Bio & 0.00 & 1.42 & 3.47 & 4.33 & 6.60 & 7.54 & 3.89 \\
\hline Vermi & 0.00 & 1.77 & 4.28 & 6.45 & 7.76 & 9.83 & 5.02 \\
\hline Vermi + K Si & 0.00 & 1.35 & 3.44 & 4.66 & 6.29 & 8.63 & 4.06 \\
\hline Vermi + Bio & 0.00 & 1.85 & 5.21 & 6.84 & 7.67 & 9.61 & 5.20 \\
\hline Means & 0.00 & 1.61 & 4.15 & 5.83 & 7.53 & 9.59 & $-\cdots$ \\
\hline \multicolumn{8}{|c|}{$2^{\text {nd }}$ season 2017} \\
\hline Control & 0.00 & 1.19 & 2.82 & 4.01 & 5.76 & 7.41 & 3.53 \\
\hline K Si & 0.00 & 1.10 & 1.96 & 2.78 & 3.83 & 4.47 & 2.36 \\
\hline K Si +Bio & 0.00 & 0.44 & 1.82 & 2.50 & 3.07 & 3.18 & 1.84 \\
\hline Vermi & 0.00 & 0.35 & 1.03 & 2.12 & 3.81 & 4.81 & 2.02 \\
\hline Vermi + K Si & 0.00 & 0.00 & 0.81 & 2.01 & 2.91 & 3.50 & 1.54 \\
\hline Vermi + Bio & 0.00 & 0.69 & 0.69 & 2.09 & 3.13 & 4.08 & 1.78 \\
\hline Means & 0.00 & 0.63 & 1.52 & 2.59 & 3.75 & 4.58 & --- \\
\hline \multicolumn{8}{|c|}{ LSD Values at $\mathbf{5 \%}$} \\
\hline Factors & \multirow{2}{*}{\multicolumn{3}{|c|}{ Treatments ( $T$ ) }} & \multicolumn{3}{|c|}{ Storage period (S) } & $T \times S$ \\
\hline $1^{\text {st }}$ season & \multirow{2}{*}{\multicolumn{3}{|c|}{$\begin{array}{l}0.37 \\
0.42\end{array}$}} & \multicolumn{3}{|c|}{0.37} & 0.92 \\
\hline $2^{\text {nd }}$ season & & & & \multicolumn{3}{|c|}{0.42} & 0.42 \\
\hline
\end{tabular}

KSi=Potassium silicate Bio= Bio-fertilizer Vermi=Vermicompost tea

Table (10): Effect of pre-harvest treatments on Decay percent of table grape (cv. ARRA15) stored at $0^{\circ} \mathrm{C}$ and $90 \% \mathrm{RH}$.

\begin{tabular}{|c|c|c|c|c|c|c|c|}
\hline \multirow{2}{*}{ Treatments } & \multicolumn{6}{|c|}{ Storage Period weeks } & \multirow{2}{*}{ Means } \\
\hline & $1^{\text {st }}$ & $2^{\text {nd }}$ & $3^{\text {rd }}$ & $4^{\text {th }}$ & $5^{\text {th }}$ & $6^{\text {th }}$ & \\
\hline \multicolumn{8}{|c|}{$1^{\text {st }}$ season 2016} \\
\hline Control & 0.00 & 0.00 & 0.00 & 0.00 & 4.60 & 8.68 & 2.21 \\
\hline K Si & 0.00 & 0.00 & 0.00 & 0.00 & 0.00 & 4.50 & 0.75 \\
\hline K Si +Bio & 0.00 & 0.00 & 0.00 & 0.00 & 0.00 & 3.60 & 0.60 \\
\hline Vermi & 0.00 & 0.00 & 0.00 & 0.00 & 0.00 & 3.68 & 0.61 \\
\hline Vermi + K Si & 0.00 & 0.00 & 0.00 & 0.00 & 0.00 & 2.10 & 0.35 \\
\hline Vermi + Bio & 0.00 & 0.00 & 0.00 & 0.00 & 0.00 & 2.69 & 0.45 \\
\hline Means & 0.00 & 0.00 & 0.00 & 0.00 & 0.77 & 4.62 & --- \\
\hline \multicolumn{8}{|c|}{$2^{\text {nd }}$ season 2017} \\
\hline Control & 0.00 & 0.00 & 0.00 & 0.52 & 3.07 & 5.83 & 1.57 \\
\hline K Si & 0.00 & 0.00 & 0.00 & 0.00 & 0.00 & 2.57 & 0.43 \\
\hline K Si +Bio & 0.00 & 0.00 & 0.00 & 0.00 & 0.00 & 1.37 & 0.23 \\
\hline Vermi & 0.00 & 0.00 & 0.00 & 0.00 & 0.00 & 1.30 & 0.22 \\
\hline Vermi + K Si & 0.00 & 0.00 & 0.00 & 0.00 & 0.00 & 0.90 & 0.15 \\
\hline Vermi + Bio & 0.00 & 0.00 & 0.00 & 0.00 & 0.00 & 1.23 & 0.21 \\
\hline Means & 0.00 & 0.00 & 0.00 & 0.09 & 0.51 & 1.98 & --- \\
\hline \multicolumn{8}{|c|}{ LSD Values at $5 \%$} \\
\hline Factors & \multicolumn{3}{|c|}{ Treatments $(T)$} & \multicolumn{3}{|c|}{ Storage period (S) } & $T \times S$ \\
\hline $1^{\text {st }}$ season & \multicolumn{3}{|c|}{0.29} & \multicolumn{3}{|c|}{0.29} & 0.72 \\
\hline $2^{\text {nd }}$ season & \multicolumn{3}{|c|}{0.15} & \multicolumn{3}{|c|}{0.15} & 0.38 \\
\hline
\end{tabular}

$\mathrm{KSi}=$ Potassium silicate Bio= Bio-fertilizer Vermi=Vermicompost tea 
2- Berries Firmness (lbs /lnch ${ }^{2}$ ):-

Data shown in Table (11) illustrated that, berry firmness decreased gradually and significantly during storage to reach its minimum values at the end of storage period during the two seasons in this study. On the other hand, it is obvious that, all preharvest treatments significantly reduced the berry firmness deterioration during storage under the two seasons of this trail. Data also cleared that, the most effective treatments in this aspect were preharvest treatments with potassium silicate either alone or in combination with bio fertilizer or vermicompost tea in the first season. While in the second season the only preharvest treatment with potassium silicate in combination with bio fertilizer has the most effective for keeping berry firmness during storage.

These results agree with those illustrated by (Mohamed and Ibrahim, 2005; Mirdehghan and Rahimi, 2016; Mohamed et al., 2017 and Sortino et al., 2017). They obtained that, berry firmness of table grape decreased gradually and significantly with prolonging of cold storage to reach its minimum values at the end of storage. Moreover, these results are in harmony with those mentioned by (Takma and Korel, 2017). They reported that, preharvest treatments with Alginate preventing grape berry firmness deterioration during cold storage.

Table (11): Effect of pre-harvest treatments on Firmness (Ibs $/ \mathrm{Inch}^{2}$ ) of table grape (cv. ARRA15) stored at $0^{\circ} \mathrm{C}$ and $90 \% \mathrm{RH}$.

\begin{tabular}{|c|c|c|c|c|c|c|c|}
\hline \multirow{2}{*}{ Treatments } & \multicolumn{6}{|c|}{ Storage Period weeks } & \multirow{2}{*}{ Means } \\
\hline & $1^{\text {st }}$ & $2^{\text {nd }}$ & $3^{\text {rd }}$ & $4^{\text {th }}$ & $5^{\text {th }}$ & $6^{\text {th }}$ & \\
\hline \multicolumn{8}{|c|}{$1^{\text {st }}$ season 2016} \\
\hline Control & 2.50 & 2.20 & 1.90 & 1.70 & 1.00 & 0.60 & 1.65 \\
\hline K Si & 3.80 & 3.40 & 2.60 & 2.40 & 1.70 & 1.30 & 2.53 \\
\hline K Si +Bio & 4.00 & 3.60 & 3.20 & 3.10 & 2.60 & 1.80 & 3.05 \\
\hline Vermi & 3.50 & 2.90 & 2.40 & 2.20 & 1.50 & 1.10 & 2.27 \\
\hline Vermi + K Si & 3.90 & 3.60 & 3.00 & 2.40 & 2.00 & 1.70 & 2.77 \\
\hline Vermi + Bio & 3.50 & 3.10 & 2.40 & 2.20 & 1.80 & 1.60 & 2.43 \\
\hline Means & 3.53 & 3.13 & 2.58 & 2.33 & 1.77 & 1.35 & -- \\
\hline \multicolumn{8}{|c|}{$2^{\text {nd }}$ season 2017} \\
\hline Control & 2.60 & 2.50 & 2.20 & 1.80 & 1.10 & 0.70 & 1.82 \\
\hline K Si & 3.50 & 3.20 & 2.40 & 2.10 & 1.90 & 1.50 & 2.43 \\
\hline K Si +Bio & 3.90 & 3.50 & 3.00 & 2.70 & 2.30 & 2.00 & 2.90 \\
\hline Vermi & 3.10 & 2.90 & 2.50 & 2.20 & 1.80 & 1.40 & 2.32 \\
\hline Vermi + K Si & 3.80 & 3.20 & 2.80 & 2.50 & 2.10 & 1.80 & 2.70 \\
\hline Vermi + Bio & 3.60 & 3.10 & 2.80 & 2.40 & 1.90 & 1.70 & 2.58 \\
\hline Means & 3.42 & 3.07 & 2.62 & 2.28 & 1.85 & 1.52 & --- \\
\hline \multicolumn{8}{|c|}{ LSD Values at $5 \%$} \\
\hline Factors & \multicolumn{3}{|c|}{ Treatments ( $T$ ) } & \multicolumn{3}{|c|}{ Storage period (S) } & $T \times S$ \\
\hline $1^{\text {st }}$ season & \multicolumn{3}{|c|}{0.1760} & \multicolumn{3}{|c|}{0.1760} & 0.4310 \\
\hline $2^{\text {nd }}$ season & \multicolumn{3}{|c|}{0.1310} & \multicolumn{3}{|c|}{0.1310} & 0.3210 \\
\hline
\end{tabular}


3-Total Soluble Solid (TSS \%) and Total acidity (TA \%):-

Data illustrated in Tables (12 and 13) declared that, in general, TSS juice contents increased while TA decreased gradually and significantly with prolonging of storage period during the two seasons in this work. However, untreated fruits TSS and TA juice contents take the same trend as the other treatments at the beginning of storage period but it had to reverse its direction at the end of storage during the two seasons in this investigation. Data also demonstrated that, all studied treatments prevented this inversion and TSS and TA juice contents changed in the same trend until the end of storage period. Moreover, these treatments decreased these changes rate during the two seasons in this investigation. Therefore, all treated bunches had TSS significantly higher and TA significantly less than untreated fruits at the end of storage period during the two seasons in this experiment.

Table (12): Effect of pre-harvest treatments on TSS (\%) of table grape (cv. ARRA15) stored at $0^{\circ} \mathrm{C}$ and $90 \% \mathrm{RH}$.

\begin{tabular}{|c|c|c|c|c|c|c|c|}
\hline \multirow{2}{*}{ Treatments } & \multicolumn{6}{|c|}{ Storage Period weeks } & \multirow{2}{*}{ Means } \\
\hline & $1^{\text {st }}$ & $2^{\text {nd }}$ & $3^{\text {rd }}$ & $4^{\text {th }}$ & $5^{\text {th }}$ & $6^{\text {th }}$ & \\
\hline \multicolumn{8}{|c|}{$1^{\text {st }}$ season 2016} \\
\hline Control & 17.50 & 18.30 & 20.60 & 21.90 & 17.60 & 16.10 & 18.67 \\
\hline K Si & 17.70 & 19.30 & 19.40 & 20.30 & 20.80 & 22.60 & 20.02 \\
\hline K Si +Bio & 18.50 & 20.70 & 22.00 & 22.80 & 23.60 & 24.00 & 21.93 \\
\hline Vermi & 17.60 & 20.70 & 20.90 & 21.40 & 22.00 & 22.30 & 20.82 \\
\hline Vermi + K Si & 18.30 & 21.00 & 22.00 & 22.50 & 23.20 & 23.80 & 21.80 \\
\hline Vermi + Bio & 18.10 & 20.70 & 21.30 & 22.10 & 22.80 & 23.40 & 21.40 \\
\hline Means & 17.95 & 20.12 & 21.03 & 21.83 & 21.62 & 22.03 & -- \\
\hline \multicolumn{8}{|c|}{$2^{\text {nd }}$ season 2017} \\
\hline Control & 17.70 & 21.10 & 21.10 & 21.50 & 18.40 & 15.90 & 19.28 \\
\hline K Si & 18.10 & 20.50 & 21.80 & 22.20 & 22.70 & 23.10 & 21.40 \\
\hline K Si +Bio & 18.50 & 21.20 & 22.40 & 22.80 & 23.10 & 24.60 & 22.10 \\
\hline Vermi & 17.80 & 20.60 & 21.70 & 22.40 & 23.10 & 23.60 & 21.53 \\
\hline Vermi + K Si & 18.40 & 21.60 & 21.60 & 22.30 & 23.50 & 24.80 & 22.03 \\
\hline Vermi + Bio & 18.10 & 21.00 & 22.00 & 22.50 & 23.50 & 24.10 & 21.87 \\
\hline Means & 18.10 & 21.00 & 21.77 & 22.28 & 22.38 & 22.68 & -- \\
\hline \multicolumn{8}{|c|}{ LSD Values at $5 \%$} \\
\hline Factors & \multicolumn{3}{|c|}{ Treatments $(T)$} & \multicolumn{3}{|c|}{ Storage period (S) } & $T \times S$ \\
\hline $1^{\text {st }}$ season & \multicolumn{3}{|c|}{0.59} & \multicolumn{3}{|c|}{0.59} & 1.43 \\
\hline $2^{\text {nd }}$ season & \multicolumn{3}{|c|}{0.22} & \multicolumn{3}{|c|}{0.22} & 0.54 \\
\hline
\end{tabular}

KSi=Potassium silicate $\quad$ Bio= Bio-fertilizer Vermi=Vermicompost tea 
Table (13): Effect of pre-harvest treatments on total acidity (\%) of table grape (cv. ARRA15) stored at $0^{\circ} \mathrm{C}$ and $90 \% \mathrm{RH}$.

\begin{tabular}{|c|c|c|c|c|c|c|c|}
\hline \multirow{2}{*}{ Treatments } & \multicolumn{6}{|c|}{ Storage Period weeks } & \multirow{2}{*}{ Means } \\
\hline & $1^{\text {st }}$ & $2^{\text {nd }}$ & $3^{\text {rd }}$ & $4^{\text {th }}$ & $5^{\text {th }}$ & $6^{\text {th }}$ & \\
\hline \multicolumn{8}{|c|}{$1^{\text {st }}$ season 2016} \\
\hline Control & 1.010 & 0.950 & 0.900 & 0.820 & 0.750 & 0.350 & 0.797 \\
\hline K Si & 1.020 & 0.900 & 0.850 & 0.795 & 0.710 & 0.650 & 0.821 \\
\hline K Si +Bio & 1.030 & 0.850 & 0.810 & 0.780 & 0.690 & 0.610 & 0.795 \\
\hline Vermi & 0.900 & 0.840 & 0.830 & 0.800 & 0.730 & 0.660 & 0.793 \\
\hline Vermi + K Si & 1.000 & 0.860 & 0.830 & 0.785 & 0.710 & 0.620 & 0.801 \\
\hline Vermi + Bio & 1.010 & 0.870 & 0.840 & 0.790 & 0.730 & 0.640 & 0.813 \\
\hline Means & 0.995 & 0.878 & 0.843 & 0.795 & 0.720 & 0.588 & -- \\
\hline \multicolumn{8}{|c|}{$2^{\text {nd }}$ season 2017} \\
\hline Control & 1.100 & 0.940 & 0.910 & 0.700 & 0.500 & 0.300 & 0.742 \\
\hline K Si & 1.120 & 1.000 & 0.840 & 0.790 & 0.700 & 0.640 & 0.848 \\
\hline $\mathrm{K} \mathrm{Si}+\mathrm{Bio}$ & 1.050 & 0.870 & 0.795 & 0.750 & 0.600 & 0.500 & 0.761 \\
\hline Vermi & 1.140 & 0.900 & 0.840 & 0.790 & 0.700 & 0.650 & 0.837 \\
\hline Vermi + K Si & 0.970 & 0.880 & 0.825 & 0.770 & 0.620 & 0.600 & 0.778 \\
\hline Vermi + Bio & 1.050 & 0.895 & 0.832 & 0.780 & 0.640 & 0.620 & 0.803 \\
\hline Means & 1.072 & 0.914 & 0.840 & 0.763 & 0.627 & 0.552 & -- \\
\hline \multicolumn{8}{|c|}{ LSD Values at $5 \%$} \\
\hline Factors & \multicolumn{3}{|c|}{ Treatments $(\mathrm{T})$} & \multicolumn{3}{|c|}{ Storage period (S) } & $T \times S$ \\
\hline $1^{\text {st }}$ season & \multicolumn{3}{|c|}{0.063} & \multicolumn{3}{|c|}{0.063} & 0.154 \\
\hline $2^{\text {nd }}$ season & \multicolumn{3}{|c|}{0.056} & \multicolumn{3}{|c|}{0.056} & 0.136 \\
\hline
\end{tabular}

$\mathrm{KSi}=$ Potassium silicate $\quad$ Bio= Bio-fertilizer Vermi=Vermicompost tea

These results are in accordance with those illustrated by (Mohamed and Ibrahim, 2005; Mohamed et al., 2007; ElZayat and Mohamed, 2008; Mirdehghan and Rahimi, 2016; Mohamed et al., 2017 and Sortino et al., 2017). They found that, TSS increased gradually and significantly while TA decreased gradually and significantly with prolonging of storage period.

\section{4-Total sugars percentage:}

As shown in Table 14, preharvest foliar application treatments by KSi plus addition biofertilizer and $\mathrm{KSi}$ with virmecompost tea recorded the highest berry sugars percentage $(17.82,17.57 \& 17.92,17.75 \%)$ followed by virmecompost tea plus addition biofertilizer $(17.25,17,73 \%)$, while the lowest sugars percentages (15.12, $15.80 \%)$ were recorded by control berries at initial time of cold storage, in both seasons, respectively. Moreover, spraying table grapes clusters by KSi or virmecompost tea alone increased berry sugars percentage more than control and recorded (16.72, 16.78 and17.07, 17.37\%) 
H.G. Elmehrat, et al.,

at initial time of cold storage. These results are in harmony with Nofal and Resk, (2009) who reported that, potassium influences the flavor and taste of table grapes by increasing the sugar content and the sweetness of the berries. The same trend was mentioned by (Athani et al., 1999; Arancon et al., 2004; Verma et al., 2015 and Pane et al., 2016) on tomatoes. Also they added that, using virmecompost as a soil additive increased tomatoes fruit Vitamin $\mathrm{C}$ and total sugar contents during growth and maturation. Also (Muhammad et al., 2017) show that, application of virmecompost significantly improved fruit physical and chemical characteristics like clusters weight, TSS, TA, RS, TS and yield of table grapes cv. King's Ruby. This may result in greater price in the market, since larger bunches are more appreciated in the market.

Table (14): Effect of pre-harvest treatments on total sugar (\%) of table grape (cv. ARRA15) stored at $0^{\circ} \mathrm{C}$ and $90 \% \mathrm{RH}$.

\begin{tabular}{|c|c|c|c|c|c|c|c|}
\hline \multirow{2}{*}{ Treatments } & \multicolumn{6}{|c|}{ Storage Period weeks } & \multirow{2}{*}{ Means } \\
\hline & $1^{\text {st }}$ & $2^{\text {nd }}$ & $3^{\text {rd }}$ & $4^{\text {th }}$ & $5^{\text {th }}$ & $6^{\text {th }}$ & \\
\hline \multicolumn{8}{|c|}{$1^{\text {st }}$ season 2016} \\
\hline Control & 13.30 & 16.30 & 16.60 & 17.60 & 14.10 & 12.80 & 15.12 \\
\hline K Si & 14.10 & 16.20 & 16.50 & 17.30 & 17.70 & 18.50 & 16.72 \\
\hline K Si +Bio & 15.00 & 17.20 & 17.60 & 18.20 & 18.80 & 20.10 & 17.82 \\
\hline Vermi & 14.30 & 16.50 & 17.00 & 17.70 & 18.20 & 18.70 & 17.07 \\
\hline Vermi + K Si & 14.90 & 16.80 & 17.60 & 18.00 & 18.50 & 19.60 & 17.57 \\
\hline Vermi + Bio & 13.90 & 17.10 & 17.50 & 17.80 & 18.30 & 18.90 & 17.25 \\
\hline Means & 14.25 & 16.68 & 17.13 & 17.77 & 17.60 & 18.10 & --- \\
\hline \multicolumn{8}{|c|}{$2^{\text {nd }}$ season 2017} \\
\hline Control & 13.70 & 16.70 & 17.90 & 18.20 & 15.20 & 13.10 & 15.80 \\
\hline K Si & 14.50 & 15.80 & 16.30 & 17.55 & 18.00 & 18.50 & 16.78 \\
\hline K Si +Bio & 15.30 & 16.20 & 16.80 & 18.80 & 19.60 & 20.80 & 17.92 \\
\hline Vermi & 14.20 & 16.50 & 17.60 & 18.20 & 18.50 & 19.20 & 17.37 \\
\hline Vermi + K Si & 15.10 & 16.80 & 17.30 & 17.90 & 19.00 & 20.40 & 17.75 \\
\hline Vermi + Bio & 14.50 & 16.90 & 17.50 & 18.50 & 19.00 & 20.00 & 17.73 \\
\hline Means & 14.55 & 16.48 & 17.23 & 18.19 & 18.22 & 18.67 & --- \\
\hline \multicolumn{8}{|c|}{ LSD Values at $5 \%$} \\
\hline Factors & \multicolumn{3}{|c|}{ Treatments (T) } & \multicolumn{3}{|c|}{ Storage period (S) } & T×S \\
\hline $1^{\text {st }}$ season & \multicolumn{3}{|c|}{0.47} & \multicolumn{3}{|c|}{0.47} & 1.15 \\
\hline $2^{\text {nd }}$ season & \multicolumn{3}{|c|}{0.18} & \multicolumn{3}{|c|}{0.18} & 0.44 \\
\hline
\end{tabular}

KSi=Potassium silicate Bio= Bio-fertilizer Vermi=Vermicompost tea 


\section{Conclusion}

Based on the results of this study, it can be concluded, the application of KSi plus addition of biofertilizer and KSi with virmecompost tea combination treatments as foliar application at version had more pronounced positive effect on berry quality of "ARRA15" table grapes during storage at $0^{\circ} \mathrm{C}$ and $90 \% \mathrm{RH}$. Such combined effect would enhance the storage period of grapes by efficiently delaying reduction of fresh weight, TSS, TS, berry decay.

\section{REFERENCES}

Abd El-Razek, E., D. Treutter, M.M.S. Saleh, M. El-Shammaa, A.A. Fouad and N. Abdel-Hamid (2011). Effect of nitrogen and potassium fertilization on productivity and fruit quality of 'crimson seedless' grape. Agriculture and Biology Journal of North America, 2, 2:330-340.

Alrashdi, A. M. A., A. D. Al-Qurashi, M. A. Awad, S. A. Mohamed and A. A. Alrashdi (2017). Quality, antioxidant compounds, antioxidant capacity and enzymes activity of 'El-Bayadi' table grapes at harvest as affected by preharvest salicylic acid and gibberellic acid spray. Scientia Horticulturae, 220: 243-249.

A.O.A.C. (2003). Association of Official Agricultural Chemists 16th ed., Benjamin Franklin Station, Washington, D.C., U.S.A. pp.490- 510.

Arancon, N.Q., C.A. Edwards, P. Bierman, C. Welch and J.D. Metzger (2004). Influences of virmecompost on field strawberries: 1. Effects on growth and yields. Bioresource Technology 93: 145-153

Arancon, N.Q., J.D. Metzger and C.A. Edwards (2005). Effects of virmecompost on plant growth. ISWVT, Los Banos, Philippines Nov., 16-18.
Athani, S.I., N.C. Hulamanai and A. M. Shirol (1999). Effect of vermicompost on the maturity and yield of banana. South Indian Horticulture 47: 4-7.

Bhat, J.V. and P. Khambata (1996). Role of earth worms in agriculture. Indian Council of Agriculture Research, New Delhi, 22, 36. (From Adhikary 2012).

Davies, C., R. Shin, W. Liu, M.R. Thomas and D.P. Schachtman (2006). Transporters expressed during grape berry (Vitis vinifera, L.) development are associated with an increase in berry size and berry potassium accumulation. J. Experimental Botany, 57: 3209-3216.

Edwards, C.A., J. Dominguez and N.Q. Arancon (2004). The influence of vermicompost on plant growth and pest incidence pp. 396-420 In S.H. Shakir, and W.Z.A. Mikhail, (Eds.). Soil zoology in sustainable development in the 21st century, El, Cairo, Egypt.

El-Zayat, H.E. and M.A.A. Mohamed (2008). Influence of Preharvest Application with Ethrel and Biological oil on Fruit Quality and Maturation of Crimson Seedless Table Grape. Minufia J. Agric. Res., 33(6): 14831495.

Jackson, M. L. (1973). Soil Chemical analysis perentice Hall Inc. Englewoofd Cliffs, N.J., p 331.

Javed, M., K.S. Khan, M. Akmal and K.M. Qureshi (2017). Vermicompost application improves yield and quality of table grapes var. king's ruby (Vitis vinifera). International Journal of Biosciences, 10(1): 152-164.

Kelany, A., E. Sahar, M. Abdel-Wahab, A.A. Abdel-Hafeez and I.A. Emam (2011). Effect of Pre-harvest treatments on cluster quality of "Flame Seedless" table grape cultivar during cold storage. Journal of Horticultural Science \& Ornamental Plants 3(1): 11-21. 
Lo'ay, A.A. and M.S. EL-Boray (2018). Improving fruit cluster quality attributes of 'Flame Seedless' grapes using preharvest application of ascorbic and salicylic acid. Scientia Horticulturae, 233: 339-348.

Lo'ay, A.A. (2017). Preharvest salicylic acid and delay ripening of 'superior seedless' grapes. Egyptian Journal of Basic and Applied Sciences, 4(3):227230.

Meng, X., B. Li, J. Liu and S. Tian (2008). Physiological responses and quality attributes of table grape fruit to chitosan preharvest spray and postharvest coating during storage. Food Chem., 106: 501-508

Mirdehghan, S.H. and S. Rahimi (2016). Pre-harvest application of polyamines enhances antioxidants and table grape (Vitis vinifera L.) quality during postharvest period. Food Chemistry, 196: 1040-1047.

Mohamed, M., A.A. Aisha, S.A. Gaser and A.A. AbdElghany (2007). Influence of Seaweed Extract (Acadian), EDTACalcium, Ascorbic Acid and Gibberellic Acid Pre harvest Application on Crimson Seedless Table Grape: II- Storability. Egypt. J. Agric. Res., 85(6): 2257-2277.

Mohamed, M.A.A., A.F. Abd El-khalek and H.G. Elmehrat (2017). Improving Mango Fruits (Zibda CV.) Quality and Storability by preharvest application with Potassium Silicate, Chitosan and calcium chloride, Egypt. J. Hort. 44(1): 17-32.

Mohamed, A.M.A., F.H. Abdel-Aziz, M.A. Mohamed and A. Gobara (2013). Effect of foliar application of Sida compound fertilizer on growth, yield, and fruit chemical composition of 'early superior' grapevine. Journal of Horticultural Research, 21(2): 53-57.

Mohamed, M.A.A. and F.E. Ibrahim (2005). Effect of Some Viticulture Practices on Fruit Quality at Harvest and Storability of Thompson Seedless Grape. Annals of Agric. Science, Moshtohor, 43(4): 1873-1902.

Muhammad, J., K.S. Khalid, A. Muhammad and M.Q. Khalid (2017). Vermicompost application improves yield and quality of table grapes var. king's ruby (Vitis vinifera) Inter. J. of Biosc. 10, 1:152-164.

Muscolo, A., F. Bovalo, F. Gionfriddo and F. Nardi (1999). Earthworm humic matter produces auxin-like effects on Daucus carota cell growth and nitrate metabolism. Soil Biology and Biochemistry, 31, 9: 1303-1311.

Nenthra, N.N., K.V. Jayaprasad and R.D. Kale (1999). China aster [(Callistephus chinensis L.) Ness] cultivation using vermicompost as organic amendment. Crop Research Hisar. 17: 209-215.

Nofal, O.A. and A.I. Rezk (2009). Role of fertilization in improving quality of some agricultural crops. International J. Academic Res., 1: 59- 64.

Obenland, D., E. Feliziani, S. Zhu, X. Zhao, D.A. Margosan, F. M. Gabler, S. VanZyl, G. Romanazzi, J.L. Smilanick, D. Beno-Moualem, T. Kaplunov and A. Lichter (2015). Potassium application to table grape clusters after veraison increases soluble solids by enhancing berry water loss. Scientia Horticulturae, 187: 58-64.

Pane, C., A. M. Palese, R. Spaccini, A. Piccolo, G. Celanop and M. Zaccardelli (2016). Enhancing sustainability of a processing tomato cultivation system by using bioactive compost tea. Scientia Horticulturae, 202: 117-124.

Saleh, M. M., N. E. Ashour, M. H. ElSheikh and M. A. A. El-Naggar (2007). Foliar sprays of potassium dihydrogen phosphate and their impact on yield, fruit quality and controlling powdery mildew disease of "Thompson seedless" grapevines. American Eurasian J. Agric. and Environ. Sci., 2: 133-140.

Sendecor, G. W. and W. G. Cochran (1990). Statistical methods 7th Ed.The 
lowa State Univ.Press Amer. lowa USA p. 593.

Shen, Y. and H. Yang (2017). Effect of preharvest chitosan-g-salicylic acid treatment on postharvest table grape quality, shelf life, and resistance to Botrytis cinerea-induced spoilage. Scientia Horticulturae, 224: 367-373.

Sortino, G., A. Allegra, R. Passafiume, G. Gianguzzi, G. Gullo and A. Gallotta (2017). Postharvest application of sulphur dioxide fumigation to improve quality and storage ability of "red globe" grape cultivar during long cold storage, Chemical Engineering Transactions, 58: 403-408 DOI: 10.3303/CET1758068

Takma, D.K. and F. Korel (2017). Impact of preharvest and postharvest alginate treatments enriched with vanillin on postharvest decay, biochemical properties, quality and sensory attributes of table grapes. Food Chemistry, 221:187-195.

Ushakumari, K., P. Prabhakumai and P. Padmaja (1999). Efficiency of vermicompost on growth and yield of summer crop okra (Abelmoscus esculentus Moench). Journal of Tropical Agriculture 37, 87-88.

Uwakiem, M. Kh. (2015). Effect of Spraying Silicon, Selenium and Humic Acid on Fruiting of Early Sweet
Grapevines. Egypt. J. Hort. 42, 1: 333 343.

Venkatesh, P.B., S. Patil, C.V. Patil and R.S. Giraddi (1998). Effect of in situ vermiculture and vermicompost availability and plant concentration of major nutrients in grapes. Karnataka J. of Agri. Sci., 11:117-121.

Verma, S., A. Sharma, R. Kumar, C. Kaur, A. Arora, R. Shah and L. Nain (2015). Improvement of antioxidant and defense properties of Tomato (var. Pusa Rohini) by application of bio augmented compost. Saudi Journal of Biological Sciences, 22, 3: 256-264.

Zhang, M., Y. Liang and G. Chu (2017). Applying silicate fertilizer increases both yield and quality of table grape (Vitis vinifera L.) grown on calcareous grey desert soil. Scientia Horticulturae, 225: 757-763.

Zoffoli, J. P., B. A. Latorre and P. Naranjo (2008). Hairline, a postharvest cracking disorder in table grapes induced by sulfur dioxide. Postharvest Biol. Technol., 47: 90-97

Zoffoli, J. P., B. A. Latorre and P. Naranjo (2009). Preharvest applications of growth regulators and their effect on postharvest quality of table grapes during cold storage. Postharvest Biol. Technol., 51: 183-192. 
تأثير سيليكات البوتاسيوم والفيرميكمبوست تي والمخصبات الحيوية علي القدرة التخزينية

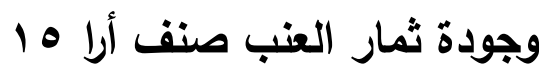

حسن جابر المحرات(") ، عادل محمد ربيع عبد اللطيف عبد العزيز (')، مدمبل

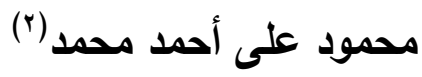

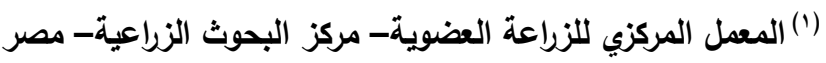

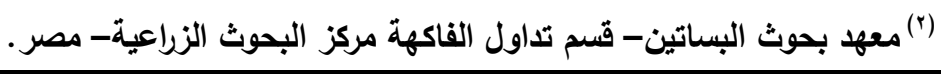

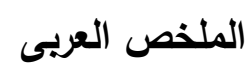

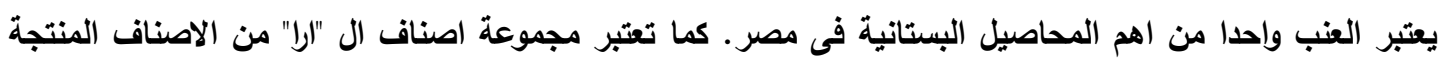

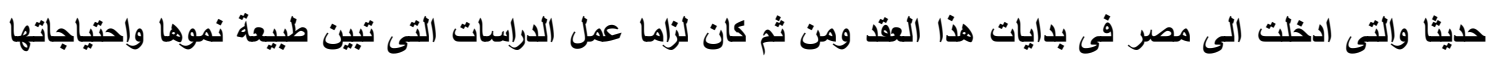

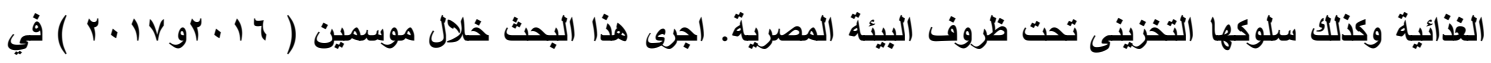

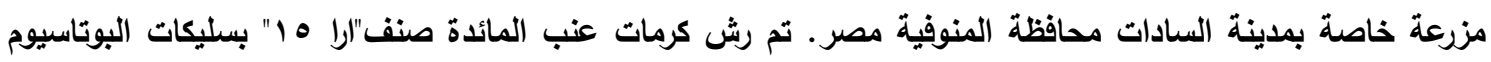

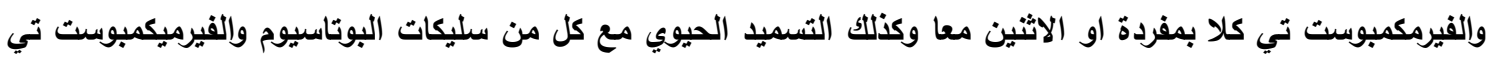

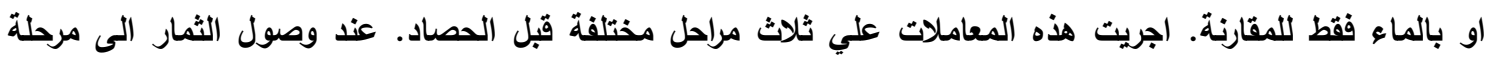

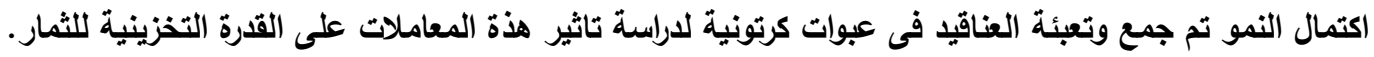

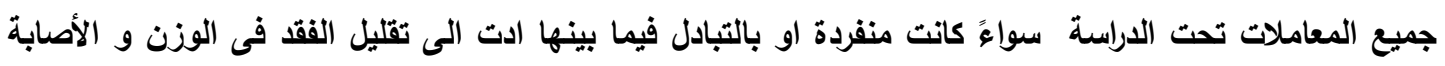

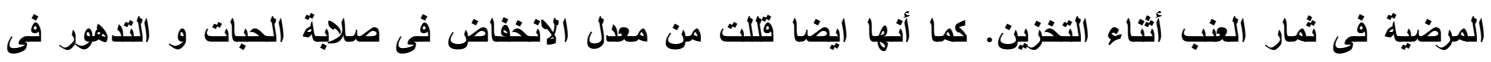
خصائص الجودة للغناقيد اثثاء التخزين مقارنة بالثمار غير المعاملة. 
